\title{
Analysis of English Alive Textbook in Terms of Genres and Lexical Density
}

\author{
Leffi Noviyenty ${ }^{1}$ \\ DOI: 10.35445/alishlah.v13i2. 587
}

\begin{tabular}{l}
\hline Article Info \\
\hline Keywords: \\
English reading \\
materials \\
Genre \\
Lexical density \\
Textbook
\end{tabular}

Kata kunci:

Materi bacaan bahasa

Inggris

Genre

Kepadatan leksikal

Buku teks

\begin{abstract}
The current study aimed at analyzing an English textbook titled English Alive used by English teachers from some senior high schools in Curup, Bengkulu, Indonesia. The textbook analysis was oriented towards two domains, namely genres and lexical density, by applying a content analysis method. This study revealed that the English Alive textbook had five genres: reading materials in the narrative, report, analytical exposition, spoof, and hortatory exposition. Those genres were embedded in sixteen passages distributed to the entire textbook, and those passages were mapped into ten units. Lexical density measurement indicated that most of the passages were categorized as easy to be comprehended, and a few passages were categorized as too easy to be comprehended. However, text genres in this textbook did not sufficiently conform to the distribution of English reading materials as suggested by the K13 curriculum. Some reading passages did not seem contributive to students' English acquisition according to comprehensible input theory and other related findings. Hence, the English Alive textbook could be used in today's context and needs as supplementary material, but the primary reading materials should be resting upon K-13-driven English textbooks. Strength and weaknesses were also identified from the English Alive textbook. The former could be noted that this textbook adopted the constructivism theory and genrebased approach properly. However, the latter indicated that the provision of genre materials did not entirely conform to essential competencies formulated in the current K-13 curriculum of English education. Further studies could analyze more textbooks to help teachers choose appropriate English textbooks.
\end{abstract}

\begin{abstract}
Abstrak
Penelitian ini bertujuan untuk menganalisis buku teks bahasa Inggris berjudul English Alive yang digunakan oleh guru bahasa Inggris dari beberapa SMA di Curup, Bengkulu, Indonesia. Analisis buku teks berorientasi pada dua domain, yaitu genre dan kepadatan leksikal, dengan menerapkan metode analisis isi. Penelitian ini mengungkapkan bahwa buku teks English Alive memiliki lima genre sebagai bahan bacaan berupa teks naratif, report, eksposisi analitik, spoof, dan teks eksposisi hortatori. Genre tersebut tertanam dalam enam belas bagian yang didistribusikan ke seluruh buku teks, dan bagian tersebut dipetakan menjadi sepuluh unit. Pengukuran kepadatan leksikal menunjukkan bahwa sebagian besar bagian dikategorikan mudah untuk dipahami, dan beberapa bagian dikategorikan terlalu mudah untuk dipahami. Namun, genre teks dalam buku teks ini tidak cukup sesuai dengan distribusi bahan bacaan bahasa Inggris sebagaimana yang disarankan oleh kurikulum K-13, dan beberapa bacaan tampaknya tidak berkontribusi pada penguasaan bahasa Inggris siswa menurut teori input yang dapat dipahami dari temuan terkait. Oleh karena itu, buku teks English
\end{abstract}

\footnotetext{
${ }^{1}$ Insitut Agama Islam Negeri (IAIN) Curup, Bengkulu, Indonesia

Email: leffinoviyenty@iaincurup.ac.id
} 
Alive tidak disarankan untuk digunakan dalam konteks dan kebutuhan saat ini. Keunggulan dan kelemahan juga diidentifikasi dari buku teks English Alive. Terkait keunggulan, dapat dicatat bahwa buku teks ini telah mengadopsi teori konstruktivisme dan pendekatan berbasis genre dengan cara yang tepat. Namun, terkait kelamahan, terlihat bahwa penyajian materi genre tidak sesuai dengan kompetensi dasar yang dirumuskan dalam kurikulum K-13 pendidikan bahasa Inggris saat ini. Studi lebih lanjut dapat menganalisis lebih banyak buku teks untuk membantu guru memilih buku teks bahasa Inggris yang sesuai.

\section{INTRODUCTION}

English as a foreign language in Indonesia makes reading skills critical since Indonesian English users tend to be more oriented towards getting engaged in written communication than oral communication (Lauder, 2008). Among many factors contributing to the foregoing nature, one of the main influential factors is the smaller probability of spoken English communicative events that occur and the bigger plausibility of written English communicative events (Kirkpatrick, 2018). For this reason, the processes of English teaching and learning in the context of Indonesia are established to embed more students' competencies in written communication through instilling various English genres and texts into the Indonesian EFL curriculum (Setyono \& Widodo, 2019). The priority of English reading skills has been evident in the educational curriculum of Indonesia since the application of competency-based curriculum or KBK, 2006's curriculum or the so-called KTSP, and today's K-13 curriculum (Morganna, 2017; Setyono \& Widodo, 2019).

To promote students' fluent and interactive reading (Kalaycı \& Diken, 2020; Thomas et al., 2019), it is recommended that English reading skill be taught through the application of genrebased instruction since this approach scaffolds students' constructive metacognition in dealing with communication mediated by a written model ( $\mathrm{Li}$ et al., 2019; Uzun \& Topkaya, 2019; Worden, 2018). Genre-based instruction is an approach to teaching a language underpinned by a constructivist paradigm (Allen, 2004; Vygotsky, 1978). This approach views the staging of communication from the presence of various genres. In this regard, genres are the realistic representations of language uses wherein genres portray the purposes, contexts, and discourses of communication (Fauziati, 2014). In terms of reading, genres determine the extent to which a reader can comprehend a text read (Dickens \& Meisinger, 2017). Genres are also the representations of language uses based on the existing socio-cultural and multicultural contexts. Since Indonesian people (or students in the realm of education) are culturally different and linguistically diverse in terms of their vernaculars, the use of English as a foreign language always comes across multilingual and multicultural settings (Kirkpatrick, 2018; Mauranen, 2018; Morganna et al., 2020; Noviyenty et al., 2020; Sherman, 2018; Wright \& Zheng, 2018). In such a way, the role of genres is more critical in English use among Indonesian students. In Indonesia, the term genre-based instruction has been familiar since the enactment of the KBK curriculum continuously followed by the KTSP curriculum, but the term shifts to a scientific approach in the K-13 curriculum. However, regardless of such a different term, the essence of the scientific approach in teaching reading skills is still similar to genre-based instruction with four main components: building knowledge, modeling, joint construction, and unique construction (Fauziati, 2014). In applying genre-based instruction, besides the importance of a constructivist paradigm, materials also play a critical role in helping students acquire reading skills. One of the suitable materials is textbooks containing an adequate amount of genre-based input in texts.

According to Richards (2001), reading materials, for instance, textbooks, can be ideally used by language teachers because such materials provide much language input to students. Hence, the preceding premise calls for the conduction of textbook analysis so that textbooks deployed as learning materials can constructively help students acquire English reading skills to a greater extent as desirable. There are many prior studies already conducted English textbook analyses. Those studies incorporate various domains as the main orientations of the analyses. Those domains can 

be mapped into several themes. Some prior studies conducted textbook analyses in terms of linguistics such as vocabulary items (Zawahreh, 2012), morphology (Roth, 2017), and grammar (Lee, 2006); multimodal resources (Joo et al., 2019; Subakir et al., 2012); cultural content (Pashmforoosh \& Babaii, 2015; Rahim \& Daghigh, 2019; Shin et al., 2011; Su, 2014; Zhili, 2014); multiculturality (Babaii \& Sheikhi, 2017; Bhandari, 2019; Cho \& Park, 2014; Setyono \& Widodo, 2019); the status of English such as language ideologies (Xiong \& Qian, 2012), world Englishes paradigm (Alcoberes, 2016), English as an international language (Ke, 2012; Thuy et al., 2020), and global Englishes paradigm (Syrbe \& Rose, 2017); and humanity such as moral education (Feng, 2017), students' needs (Rashidi \& Kehtarfard, 2014), and the values of peace (Gebregeorgis, 2016).

The above studies of textbook analyses have contributed to a tremendous amount of knowledge vis-a-vis the domains oriented, and English teachers need the insights revealed by those studies. However, to the best of our knowledge, very few or no studies have brought genres as the domain of textbook analysis in the last five years. This condition becomes a gap that should be filled, and it calls for many studies to conduct genre-based textbook analyses. Based on the preliminary study conducted at several senior high schools in Curup, Bengkulu, Indonesia, it was found that some schools made use of an English textbook that contained genre-based materials. However, the teachers had not undertaken genre-based textbook analysis before using it and teaching students. The textbook used was titled English Alive. Viewed from the adopted learning paradigm, the English Alive textbook is constructivism-based. As postulated in the theory of constructivism pioneered by Piaget (1937), further developed by Vygotsky (1978), and re-explained by Sjøberg (2010), this theory defines learning as the stepwise and continuous processes of knowledge construction that students take part in, whereby teachers play a role as the facilitators that scaffold students to work effectively on their zones of proximal development, the latent potential conditions in which students can socio-cognitively take a step forward to the improvement of learning. With teachers' facilitating role, students are guided to get themselves engaged in constructive ways of learning. In the English Alive textbook, a clear depiction of constructivism is portrayed in the essence of genre-based instruction as the endorsed approach of teaching and learning English. As seen from the entirety of the English Alive textbook, students' activities are designed based on four stages: building knowledge, modeling, joint construction, and independent construction. The four stages are the framework of the genre-based instruction approach (Li et al., 2019; Morganna, 2017; Uzun \& Topkaya, 2019), and each of the stages is constructivist. The first and second stages, the socalled building knowledge and modeling are the portrayals of scaffolding. The third and fourth stages, the so-called joint construction and independent construction, are the portrayals of knowledge construction. In short, both scaffolding and knowledge construction is the heart of constructivism learning theory.

Subsequently, viewed from its description, the English Alive textbook has been designed to facilitate second-grade students of senior high school in order to be able to use English in both spoken and written ways according to various contexts. This phenomenon calls for genre-based textbook analysis in order that the teachers using this textbook gain some insights regarding the degree to which this textbook can be relevant to students and can support students' reading comprehension and English acquisition. Another point of the English Alive textbook worth investigating further is that this textbook is designed to be applied in the KTSP curriculum. In contrast, today's curriculum is applied in Indonesian schools in the K-13 curriculum. The previous condition will not be problematic if the materials provided in the English Alive textbook are relevant to those of the K-13 curriculum syllabus for second-grade students of senior high school. It is true because the essence of English learning theories and pedagogical views between the two curricula is the same. The differences are only found in the aspects of some technical terms used but not the substantial aspects of related theories and pedagogy. However, such a condition calls for some scrutiny to see the relevance between English Alive textbook materials and the current suggested materials in the K-13 curriculum syllabus. For further viewing, the latest updated K-13 English syllabus for second-grade senior high school students can be accessed on Kherysuryawan's (2019) 

sma.html).

Besides genres as a discursive framework of communication, the other domain also essential to be analyzed in English textbooks is lexical density (Roth, 2017; Zawahreh, 2012). Lexical density symbolizes the extent of information presented in a text (Eggins, 1994; Nunan, 2003). According to Halliday (1985), lexical density is associated with the extent of the text's complexity, and lexical density is characterized by an ideal portion of informative words instilled in a text. To determine how far a text has dense lexis, lexical density is measured by getting the percentage due to the number of content words divided by the total number of words in a text or book (Laufer \& Nation, 1995). This means that lexical density is characterized by the number of content words in the entire text or book. Such a number represents the extent of information provided by the text or book. Some rationales are underlining the essence of lexis or vocabularies in association with second language textbooks. First, sufficient vocabularies support second language acquisition (Nation, 2014), so adequate vocabularies in the used textbooks are needed according to students' linguistic level. Second, to support students' second language acquisition, textbooks used as the materials need to be written using high-frequency words (Webb \& Nation, 2017). Third, the presence of too many technical and complex vocabularies will negatively affect comprehension of the texts (Groves, 2016). Hence, an ideal textbook has an adequate quantity of vocabulary under students' level. Thus, an ideal textbook should have a lexical density that meets students' level, contains high-frequency words, and mediates comprehension in the sense of having vocabularies that are not too difficult or technical.

The factual conditions concerning limited studies on genre-based textbook analysis in the past five years; the importance of genres in the context of English learning in Indonesia; the use of a textbook such as English alive which is not based on K-13 curriculum without conducting textbook analysis in prior; and the importance of lexical density embedded in textbooks drive the researchers to conduct the present study with the aims of doing textbook analysis on English alive textbook in terms of genres and lexical density.

\section{METHODS}

This study applied a content analysis method (Ary et al., 2010; Fraenkel et al., 2012; Gall et al., 2003) to identify genres and lexical density served in an English textbook titled English Alive. English Alive is an English textbook written for Second-grade senior high school students, especially Indonesian students, on the basis of the KTSP curriculum. The author of this book is Tri Indaryati. This book was published in 2012 by Yudhistira publisher, and it has 192 pages as a whole. Some English teachers used this textbook at a couple of senior high schools in Curup, Bengkulu, Indonesia.

The first stage conducted was to analyze text genres in the English Alive textbook. The genres were classified based on their types. The type classification was made according to genre categories as addressed by Fauziati (2014); Lin, Moore, Karen, and Beach (2000); Purba (2018); and Rahmawati, Listiyani, and Damayanti (2014). In order to make it more obviously distinctive while identifying the text types, Bhatia's (1997) model of genre analysis was adapted to analyze each type of genre in depth. Drawing upon this model, each text was reviewed according to four criteria which fell into the knowledge of the code (knowledge related to language usages), genre knowledge (e.g., communicative goal based on the ongoing discourse, communicative goal based on genre type, procedural knowledge related to content presentation, and social knowledge related to social aspects brought by the texts), sensitivity of cognitive structure (e.g. the organization of ideas), genre ownership (ability to explore ideas according to the selected genre).

At the second stage, this study worked on measuring the lexical density of each text. The measurement was done resting upon Laufer and Nation's (1995) construct of lexical density measurement, which subsumed the following criteria: identifying the content words and function words; counting the numbers of content words and function words; counting the portion of lexical 

density through the number of content words divided by the total number of words; and interpreting the value generated from the calculation in terms of the extent to which it relates to the current English curriculum applied in Indonesia, the theory of second language acquisition, and prior scientific findings in the fields of genres and texts. As a guide, according to Courtis and Hassan (2002), a text is categorized as highly lexically dense if the degree of its lexical density is in the range of $60 \%$ to $70 \%$, quite lexical density is categorized around $50-60 \%$, and a text stated to have low lexical density if the dense is around 40-50\%.

\section{FINDINGS AND DISCUSSION}

The findings of this study are discussed in accordance with the statements of problems formulated as follows: (1) what kinds of genres contain in the reading passages of the English Alive textbook? (2) What are the lexical densities of the reading passages in the English Alive textbook? Each of the findings is described and provided with supporting data. The following section presents the detailed findings of this study.

\section{Text Genres in English Alive Textbook}

Drawing upon Bhatia's (1997) model of genre analysis adapted to analyze each type of genre in-depth and the classification of text genres as addressed by Fauziati (2014); Lin, Moore, Karen, and Beach (2000); Purba (2018); and Rahmawati, Listiyani, and Damayanti (2014), five types of genres could be detected from English Alive textbook. These genres were garnered and classified after considering the knowledge of the code (knowledge related to language usages), genre knowledge (e.g., communicative goal based on the ongoing discourse, communicative goal based on genre type, procedural knowledge related to content presentation, and social knowledge related to social aspects brought by the texts), the sensitivity of cognitive structure (e.g., the organization of ideas), and genre ownership (ability to explore ideas according to the selected genre). The following table 1 displays the text genres found in the English Alive textbook and the corresponding number of passages.

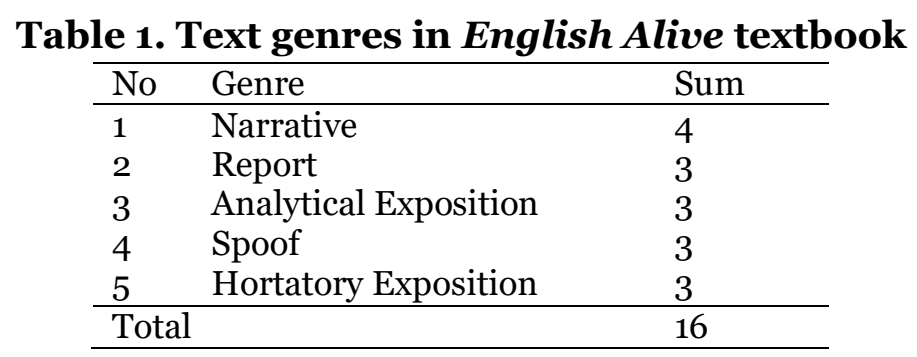

The analysis revealed that there are four narrative passages in the English Alive textbook. Some indicators characterize these passages. Their purposes are parallel, in which these passages tell stories for the sake of entertaining readers. Some similar text organizations are also identified from the four passages, representing their specific natures as narrative texts. Those organizations are orientation introducing figures in stories, complication showing the emergence and development of problems in stories, resolution telling the solutions to the problems ended in either good or bad ways, and coda or reorientation giving implications as lessons from stories.

The analysis also revealed that there are three passages in the English Alive textbook which are classified into report texts. These passages have similar purposes that provide information as it truly is. These passages also have similarly identifiable generic organizations. Their organizations are general classification informing general descriptions of objects and description providing information related to the phenomena concerning objects discussed in terms of quality, parts, habits, behavior, and others.

After analysis, there were also found three analytical exposition texts in the English Alive textbook. The passages share similar purposes, arguing perspectives, issues, or viewpoints. From the three passages, similarly identifiable generic structures are also encountered. Those structures are theses introducing topics along with the authors' related viewpoints, the argument supporting 
the authors' viewpoints by providing a variety of explanations and proofs or evidence, and reiteration drawing summaries concerning the authors' viewpoints to consolidate the theses.

As revealed from the analysis, the English Alive textbook also has three passages representing spoof texts. They share similar purposes as spoof texts, in which the purposes are to tell past-time true stories ended in unpredictable ways. These passages also share similar organizations consisting of orientation introducing figures engaged in stories and settings of the stories, events telling the stories in chronological ways, and twist entertaining readers with unpredictable endings.

The last text genre identified in the English Alive textbook according to the analysis is hortatory exposition. There are three hortatory exposition passages encountered. Those passages share similar purposes persuading readers to do something. The passages also show similar text organizations. Those organizations are theses informing problems that receive attention, Arguments giving rationales or reasons so that close attention needs to be paid to the addressed problems, and recommendations stating what should have happened.

As a whole, the English Alive textbook has sixteen passages containing five text genres. Each of those passages is given a title, as displayed in the following table.

\section{Table 2. Titles of reading passages in English Alive textbook}

\begin{tabular}{|c|c|c|c|c|c|}
\hline No & Title of reading passages & & Unit & Page & Grade \\
\hline 1 & Voice over internet protocol & & $1 \mathrm{~A}$ & $6-7$ & XI \\
\hline 2 & Conversational involvement & & $1 \mathrm{~B}$ & 16 & XI \\
\hline 3 & Friendship & & $2 \mathrm{~A}$ & $21-22$ & $\mathrm{XI}$ \\
\hline 4 & Friendster & & 2B & $29-30$ & XI \\
\hline 5 & Actor-like English instructor & & $3 \mathrm{~B}$ & $42-43$ & XI \\
\hline 6 & Use of formalin and other additives in foods & & $4 \mathrm{~B}$ & 59 & XI \\
\hline 7 & Secretary & & $5 \mathrm{~A}$ & 71 & XI \\
\hline 8 & $\begin{array}{l}\text { Street vendors: survival strategy } \\
\text { entrepreneurship? }\end{array}$ & or & $5 \mathrm{~B}$ & $76-77$ & XI \\
\hline 9 & Marriage proposal & & $6 \mathrm{~A}$ & 94 & XI \\
\hline 10 & The smartest animal & & $6 \mathrm{~B}$ & 99 & XI \\
\hline 11 & School daze & & $7 \mathrm{~A}$ & 107 & XI \\
\hline 12 & The zoo job story & & $7 \mathrm{~B}$ & 113 & XI \\
\hline 13 & Cash or charge & & $8 \mathrm{~A}$ & 122 & XI \\
\hline 14 & Be always alert & & 8B & 128-129 & XI \\
\hline 15 & We should change the payment system & & $9 \mathrm{~A}$ & 136 & XI \\
\hline 16 & Nasereddin's coat & & $10 B$ & $157-158$ & XI \\
\hline
\end{tabular}

The above titles are packed into five genres and mapped into ten units, as presented in the table below.

Table 3. Text genres and units of English Alive textbook

\begin{tabular}{|c|c|c|c|c|c|c|c|c|c|c|c|}
\hline \multirow{3}{*}{ No } & \multirow{3}{*}{ Text types } & \multicolumn{10}{|c|}{ Text genres in the textbook } \\
\hline & & & & & & & & & & & \\
\hline & & 1 & 2 & 3 & 4 & 5 & 6 & 7 & 8 & 9 & 10 \\
\hline \multirow[b]{2}{*}{1} & \multirow{2}{*}{$\begin{array}{l}\text { Narrative } \\
\text { texts }\end{array}$} & - & $2 \mathrm{~A}$ & $3 \mathrm{~b}$ & - & - & $6 \mathrm{~A}$ & - & - & - & - \\
\hline & & & & & & & $6 \mathrm{~B}$ & & & & \\
\hline \multirow{2}{*}{2} & \multirow{2}{*}{ Report texts } & $1 \mathrm{~A}$ & - & - & - & $5 \mathrm{~A}$ & - & - & - & - & - \\
\hline & & $1 \mathrm{~B}$ & - & - & - & - & - & - & - & - & - \\
\hline \multirow[t]{2}{*}{3} & $\begin{array}{l}\text { Analytical } \\
\text { exposition } \\
\text { texts }\end{array}$ & - & $2 \mathrm{~B}$ & - & $4 B$ & $5^{B}$ & - & - & - & - & - \\
\hline & \multirow{2}{*}{ Spoof texts } & - & - & - & - & - & - & $7 \mathrm{~A}$ & - & - & $10 B$ \\
\hline 4 & & - & - & _- & _- & _- & _- & $7 B$ & - & _- & _- \\
\hline
\end{tabular}




\begin{tabular}{lllllllllll}
\hline $\begin{array}{l}\text { Hortatory } \\
\text { exposition }\end{array}$ & - & - & - & - & - & - & - & $8 \mathrm{~A}$ & $9 \mathrm{~A}$ & - \\
texts & - & - & - & - & - & - & - & $8 \mathrm{~B}$ & - & - \\
\hline
\end{tabular}

\section{Lexical Density of Reading Texts in English Alive Textbook}

The lexical density symbolizes the extent of information presented in a text (Eggins, 1994; Nunan, 2003). According to Halliday (1985), lexical density is associated with the extent of text's complexity, and it is characterized by an ideal portion of informative words instilled in a text. To find out how far a text has dense lexis, lexical density is measured by getting the percentage due to the number of content words divided by the total number of words in a text or book (Laufer \& Nation, 1995). This means that lexical density is characterized by the number of content words such as nouns, adjectives, verbs, and adverbs in the entire text or book. Such a number represents the extent of information provided by the text or book. Based on the calculation of the English Alive textbook's lexical density resting upon the formula suggested by Laufer and Nation (1995), the results can be seen in the following table 4. To be noted, as informed by Laufer and Nation (1999), the textbook is considered highly lexically dense if the degree of its lexical density is in the range of $60 \%$ to $70 \%$. Its lexis is sufficient if the lexical density is categorized around 50-60\%. Subsequently, the low lexical density is demonstrated if the dense of its lexis is around $40-50 \%$.

Table 4. The percentages of the lexical density of reading passages in the English Alive textbook

\begin{tabular}{|c|c|c|c|c|c|c|c|c|}
\hline No & $\begin{array}{l}\text { Title of reading } \\
\text { text }\end{array}$ & Genre & Unit & Page & $\begin{array}{l}\text { Cont } \\
\text { ent } \\
\text { word } \\
\text { s }\end{array}$ & $\begin{array}{l}\text { Grammati } \\
\text { cal } \\
\text { function } \\
\text { words }\end{array}$ & $\begin{array}{l}\text { Lexical } \\
\text { density } \\
(\%)\end{array}$ & $\begin{array}{l}\text { Qualification of } \\
\text { lexical density }\end{array}$ \\
\hline 1 & $\begin{array}{l}\text { Voice over } \\
\text { internet } \\
\text { protocol }\end{array}$ & Report & $1 \mathrm{~A}$ & $6-7$ & 246 & 194 & $55.90 \%$ & $\begin{array}{l}\text { Easy to be } \\
\text { comprehended }\end{array}$ \\
\hline 2 & $\begin{array}{l}\text { Conversational } \\
\text { involvement }\end{array}$ & Report & 1B & 16 & 154 & 105 & $59.45 \%$ & \multirow{3}{*}{$\begin{array}{l}\text { Easy to be } \\
\text { comprehended } \\
\text { Too easy to be } \\
\text { comprehended } \\
\text { Too easy to be } \\
\text { comprehended }\end{array}$} \\
\hline 3 & Friendship & Narrative & $2 \mathrm{~A}$ & $21-22$ & 202 & 219 & $47.98 \%$ & \\
\hline 4 & Friendster & $\begin{array}{l}\text { Analytical } \\
\text { exposition }\end{array}$ & $2 B$ & $29-30$ & 138 & 134 & $49.63 \%$ & \\
\hline 5 & $\begin{array}{l}\text { Actor-like } \\
\text { English } \\
\text { instructor }\end{array}$ & Narrative & $3^{B}$ & $42-43$ & 270 & 295 & $44.85 \%$ & $\begin{array}{l}\text { Too easy to be } \\
\text { comprehended }\end{array}$ \\
\hline 6 & $\begin{array}{l}\text { Use of formalin } \\
\text { and other } \\
\text { additives } \\
\text { foods }\end{array}$ & $\begin{array}{l}\text { Analytical } \\
\text { exposition }\end{array}$ & $4 \mathrm{~B}$ & 59 & 149 & 148 & $50.16 \%$ & $\begin{array}{l}\text { Easy to be } \\
\text { comprehended }\end{array}$ \\
\hline 7 & Secretary & Report & $5 \mathrm{~A}$ & 71 & 116 & 197 & $54.46 \%$ & $\begin{array}{l}\text { Easy to be } \\
\text { comprehended }\end{array}$ \\
\hline 8 & $\begin{array}{l}\text { Street vendors: } \\
\text { survival } \\
\text { strategy or } \\
\text { entrepreneursh } \\
\text { ip? }\end{array}$ & $\begin{array}{l}\text { Analytical } \\
\text { exposition }\end{array}$ & $5 \mathrm{~B}$ & $76-77$ & 430 & 371 & $53.68 \%$ & \multirow{6}{*}{$\begin{array}{l}\text { Too easy to be } \\
\text { comprehended } \\
\text { Too easy to be } \\
\text { comprehended } \\
\text { Too easy to be } \\
\text { comprehended } \\
\text { Easy to be } \\
\text { comprehended } \\
\text { Easy to be } \\
\text { comprehended }\end{array}$} \\
\hline 9 & $\begin{array}{l}\text { Marriage } \\
\text { Proposal }\end{array}$ & Narrative & $6 \mathrm{~A}$ & 94 & 157 & 187 & $45.63 \%$ & \\
\hline 10 & $\begin{array}{l}\text { The smartest } \\
\text { animal }\end{array}$ & Narrative & $6 B$ & 99 & 101 & 113 & $47.19 \%$ & \\
\hline 11 & School daze & Spoof text & $7 \mathrm{~A}$ & 107 & 100 & 104 & $49.07 \%$ & \\
\hline 12 & $\begin{array}{l}\text { The zoo job } \\
\text { story }\end{array}$ & Spoof text & $7 \mathrm{~B}$ & 113 & 288 & 192 & $54.28 \%$ & \\
\hline 13 & Cash or charge & $\begin{array}{l}\text { Hortatory } \\
\text { exposition }\end{array}$ & $8 \mathrm{~A}$ & 122 & 235 & 214 & $52.33 \%$ & \\
\hline
\end{tabular}




\begin{tabular}{|c|c|c|c|c|c|c|c|c|}
\hline 14 & Be always alert & $\begin{array}{l}\text { Hortatory } \\
\text { exposition }\end{array}$ & $8 B$ & $\begin{array}{l}128- \\
129\end{array}$ & 255 & 216 & $54.14 \%$ & $\begin{array}{l}\text { Easy to be } \\
\text { comprehended }\end{array}$ \\
\hline 15 & $\begin{array}{l}\text { We should } \\
\text { change the } \\
\text { payment } \\
\text { System }\end{array}$ & $\begin{array}{l}\text { Hortatory } \\
\text { exposition }\end{array}$ & $9 \mathrm{~A}$ & 136 & 149 & 149 & $50 \%$ & $\begin{array}{l}\text { Easy to be } \\
\text { comprehended }\end{array}$ \\
\hline 16 & $\begin{array}{l}\text { Nasereddin's } \\
\text { coat }\end{array}$ & Spoof text & $10 B$ & $\begin{array}{l}157^{-} \\
158\end{array}$ & 104 & 95 & $54,45 \%$ & $\begin{array}{l}\text { Easy to be } \\
\text { comprehended }\end{array}$ \\
\hline
\end{tabular}

As a discussion, the present study revealed two sets of information. First, the English Alive textbook has five text genres: narrative, report, analytical exposition, spoof, and hortatory exposition. Those text genres are demonstrated by sixteen passages distributed in the entire reading materials of the textbook, and those passages are mapped into ten units. Second, according to the results of lexical density measurement, most of the passages are categorized as easy to be comprehended. A few passages are categorized as too easy to be comprehended such as all narrative texts titled friendship, actor-like English instructor, marriage proposal, and the smartest animal; one of the spoof texts titled school daze, and one of the analytical exposition texts titled Friendster.

However, there are conflicting issues if these findings are compared to the current $\mathrm{K}-13$ curriculum English materials for Indonesian students, the second language acquisition theory, and previous findings regarding text genres. Regarding the conformity of English Alive materials to those of the K-13 curriculum, considering text genres of English Alive textbooks ranging from the narrative, report, analytical exposition, spoof, to hortatory exposition texts, only analytical exposition texts concur with the English material distribution of K-13 curriculum syllabus. According to the latest updated K-13 English syllabus for second-grade senior high school students uploaded by Kherysuryawan (2019) on his BlogSpot, at (https://www.kherysuryawan.id/2019/o7/silabus-k13-bahasa-inggris-kelas-xi-sma.html), there are several points or essential competencies that English students have to achieve in terms of texts-based English. First, students are expected to distinguish social functions, text structures, and language features of certain texts in the form of official invitations in ways that give and ask for information associated with scholastic activities or activities in the workplace according to the contexts of uses. In the perspective of the genre, this competency is associated with invitation texts. Second, students are expected to distinguish social functions, text structures, and language features of several analytical exposition texts in both spoken and written modes through giving and asking for information related to actual issues according to the contexts of uses. In the perspective of the genre, this competency is pertinent to analytical exposition texts. Third, students are expected to be able to apply social functions, text structures, and language features of transactional texts in both spoken and written modes which take on some actions associated with giving and asking for information as regards conditions/actions/activities/events, without necessarily mentioning the doers if they are scientific texts, according to the contexts of uses. In the perspective of the genre, this competency is related to descriptive texts. Fourth, students are expected to distinguish social functions, text structures, and language features of certain texts in the form of personal letters in ways that give and ask for information pertinent to one's activities and others' according to the contexts of uses. In the perspective of the genre, this competency is associated with personal letters. Fifth, students are expected to distinguish social functions, text structures, and language features of several explanation texts in both spoken and written modes through giving and asking for information related to natural or social phenomena included in other subjects of eleventh grade. In the perspective of genres, this competency is related to explanation texts.

To be summarized, in descending order, the aforesaid five points of basic competencies formulated by the K-13 curriculum of English education for the second grade of senior high school demonstrate five sets of genres, namely the texts of invitation, analytical exposition, description, personal letters, and explanation. Nonetheless, if compared with the distribution of genres contained in the English Alive textbook (narrative, report, analytical exposition, spoof, and 

hortatory exposition texts), it is unfortunate that there is only one text genre, analytical exposition, which conforms to the K-13 curriculum for English subject at the second grade of senior high school. This condition indicates that the pedagogically English Alive textbook might be used but just as a supplementary material because the genres' orientation distributed in this book is not sufficiently relevant to competencies as expected by the K-13 curriculum. Thus, for the main materials, there should be used English textbooks that are more K-13-driven.

Grounded in second language acquisition theory, all narrative texts in the English Alive textbook are categorized as being too easy to comprehend in terms of lexical density. This condition implies that narrative texts in this textbook are not properly contributive to English acquisition. According to Krashen $(1981,1982,2004)$, in one of his comprehensible input theory components, language acquisition can occur if the input given is a little bit higher than students' current English proficiency. However, such input can be reached and comprehended if students make use of their current English proficiency. In English reading materials as the second language acquisition input for students, English passages that are too easy to comprehend, as demonstrated in narrative passages in the English Alive textbook, will not lead students to acquire more English vocabularies desirable. Too easy English passages will retain students' current English competence but not mediate students to acquire more.

It seems that narrative passages in the English Alive textbook are not presented ideal, promoting students to acquire more English vocabulary. English teachers using this book should be aware of this finding and should consider using another material or book to provide ideal narrative passages for students. Comprehensible input theory is quite reliable to be utilized to argue this part of finding because this theory has already been examined and supported by prior studies conducted by Edwards, Wesche, Krashen, Clement, and Kruidenierr (1985); Hauptman, Wesche, and Ready (1988); and Lafayette and Buscaglia (1985) who examined the effectiveness of second language instructions applying comprehensible input theory. Other studies are carried out by Elley (1991), Elley and Mangubhai (1983), and Mason and Krashen (1997), who examined comprehensible input theory employing extensive reading as the learning treatment.

The other part of the current finding worth arguing is that resting upon lexical density measurement, one of the analytical exposition texts titled Friendster is identified as too easy to comprehend. An analytical exposition text or the so-called expository text is one type of English genre considered as the most difficult one since this genre engages readers into dealing with various arguments and viewpoints to the extent of scientific ways at some point. Many prior studies support the preceding generalization corresponding to the problematic nature of expository texts. Among those studies are the ones conducted by Clariana, Wolfe, and Kim (2014); Marmolejo-ramos, Miller, and Habel (2014); and Saadatnia, Tavakoli, and Ketabi (2016). Such an analytical exposition text titled Friendster provided by the English Alive textbook does not seem effective if used as an English reading input. Such a text does not seem to support students' further English acquisition. As a whole, anchored in the current updated K-13 English syllabus for second-grade senior high school students; and the in conformity of some passages provided in English Alive textbook to comprehensible input theory and some prior findings revealed from studies on English genres and texts, it can be stated that English Alive textbook is not recommended to be used today. It is not relevant to students' current needs.

Implied by the present study's data, there are strengths and weaknesses of the English Alive textbook which can be drawn. In terms of strength, this textbook has adopted the constructivism theory and genre-based approach in proper ways as proven from the data that the textbook uses varied genre-based materials in an ideal distribution, namely four narrative texts, three report texts, three analytical exposition texts, three spoof texts, and three hortatory exposition texts. The activities under each text have been designed constructively based on scaffolding and knowledge construction as the heart of the constructivism paradigm. Subsequently, the essence of scaffolding has been demonstrated by building knowledge and modeling activities following each text. The essence of knowledge construction has been exhibited by joint and independent construction 
activities under each text. However, this textbook is not free from weaknesses. As can be traced from the data of this study, the provision of genre materials does not conform to basic competencies formulated in the current K-13 curriculum of English education. In brief, the K-13 curriculum for English subjects at the second grade of senior high school formulates basic competencies that students can work with official invitations, analytical expositions, descriptions, personal letters, and explanations. Meanwhile, of English Alive genres (narrative, report, analytical exposition, spoof, and hortatory exposition texts), only analytical exposition texts conform to one of the K-13 curriculum basic competencies. This means that the materials of the English Alive textbook are not aligned with those suggested by the K-13 curriculum for English subjects at the second grade of senior high school.

As an implication, the entirety of the present study highlights two indicators as part of the English textbook. The first indicator is the importance of genres and their distribution based on the currently used curriculum. The second indicator of the importance of sufficient density of lexis an English textbook has to provide in its materials. These are two critical indicators of English textbook selection or textbook development that deserve consideration besides other indicators of English textbook that other studies have worked on, for instance, the indicators of vocabulary items (Zawahreh, 2012), morphology (Roth, 2017), grammar (Lee, 2006), multimodal resources (Joo et al., 2019; Subakir et al., 2012), cultural contents (Pashmforoosh \& Babaii, 2015; Rahim \& Daghigh, 2019; Shin et al., 2011; Su, 2014; Zhili, 2014), multiculturalism (Babaii \& Sheikhi, 2017; Bhandari, 2019; Cho \& Park, 2014; Setyono \& Widodo, 2019), language ideologies (Xiong \& Qian, 2012), world Englishes paradigm (Alcoberes, 2016), the paradigm of English as an international language (Ke, 2012; Thuy et al., 2020), global Englishes paradigm (Syrbe \& Rose, 2017); moral education (Feng, 2017), students' needs (Rashidi \& Kehtarfard, 2014), and the values of peace (Gebregeorgis, 2016). The present study contributes to providing important highlights of appropriate genre distribution and lexical density. Two indicators of English textbooks and other indicators have been addressed by previous studies mentioned in the foregoing.

\section{CONCLUSION}

The analysis of the English Alive textbook yields two sets of information. First, the English Alive textbook has five text genres: narrative, report, analytical exposition, spoof, and hortatory exposition. Those text genres are demonstrated by sixteen passages distributed in the entire reading materials of the textbook, and those passages are mapped into ten units. Second, according to the results of lexical density measurement, most of the passages are categorized as easy to be comprehended. A few passages are categorized as too easy to be comprehended such as all narrative texts titled friendship, actor-like English instructor, marriage proposal, and the smartest animal; one of the spoof texts titled school daze, and one of the analytical exposition texts titled Friendster. Grounded in the English syllabus of today's curriculum for second-grade students of senior high school, reading materials in the English Alive textbook is not relevant to the distribution of K-13 English reading materials. Subsequently, the analysis also indicates that all narrative passages and one of the analytical exposition passages provided in the English Alive textbook do not seem to contribute to students' further English acquisition as argued based upon comprehensible input theory and some prior related findings. Accordingly, based on the whole results of the analysis, the English Alive textbook might be used as supplementary material because the genres' orientation distributed in this book is not sufficiently relevant to competencies as expected by the K-13 curriculum. Thus, for the main materials, there should be used English textbooks that are more K13-driven.

Strength and weaknesses are identified from the English Alive textbook. The former can be noted that this textbook has adopted the constructivism theory and genre-based approach properly, as proven from the data that the textbook uses varied genre-based materials in an ideal distribution. The activities under each text have been designed constructively based on scaffolding and 

knowledge construction as the heart of the constructivism paradigm. Subsequently, the essence of scaffolding has been demonstrated by building knowledge and modeling activities following each text. The essence of knowledge construction has been exhibited by joint and independent construction activities under each text. However, the latter can also be traced from the data of this study, in which the provision of genre materials does not conform to essential competencies formulated in the current K-13 curriculum of English education. In brief, the K-13 curriculum for English subjects at the second grade of senior high school formulates essential competencies that students can work with official invitations, analytical expositions, descriptions, personal letters, and explanations. Meanwhile, of English Alive genres (narrative, report, analytical exposition, spoof, and hortatory exposition texts), only analytical exposition texts conform to one of the K-13 curriculum basic competencies. This means that the materials of the English Alive textbook are not aligned with those suggested by the K-13 curriculum for English subjects at the second grade of senior high school.

This study is limited to merely the analysis of one genre-based English textbook. Such a limitation leads to the conduction of more inductive analysis instead of deductive analysis. In a nutshell, the present study's findings are qualitative and contextual because they cannot be generalized to other contexts without in-depth critical considerations. However, this study has brought various generalized theories of second language acquisition (e.g., comprehensible input theory) as part of theoretical triangulation efforts to verify the current findings. The data of the present study help draw an implication in which the entirety of the present study highlights two indicators as part of the English textbook. The first indicator is the importance of genres and their distribution based on the currently used curriculum. The second indicator is the importance of sufficient density of lexis an English textbook has to provide in its materials. These are two critical indicators of English textbook selection or textbook development that deserve considerations besides other indicators of English textbook that other studies have worked on, for instance, the indicators of vocabulary items, cultural contents, multiculturalism, language ideologies, world Englishes paradigm, the paradigm of English as an international language, global Englishes paradigm; moral education, students' needs, and the values of peace. The present study contributes to providing important highlights of appropriate genre distribution and lexical density as two indicators of English textbooks and other indicators that previous studies mentioned in the foregoing. Further studies are expected to examine other English textbooks commonly used by English teachers in Indonesia so that various in-depth data can be revealed and learned by English teachers to support their decision-making in English textbook selection for English instructions.

\section{REFERENCES}

Alcoberes, P. J. N. (2016). The author-initiated discourses in the selected English textbooks in Southeast Asia: a World Englishes paradigm. Asian Englishes, 1-17. https://doi.org/10.1080/13488678.2015.1132109

Allen, L. Q. (2004). Implementing a culture portfolio project within a constructivist paradigm. Foreign Language Annals, 37(2), 232-239. https://doi.org/10.1111/j.19449720.2004.tbo2196.x

Ary, D., Jacobs, L. C., Sorensen, C. K., Walker, D. A., \& Razavieh, A. (2010). Introduction to research in education. In measurement (8th ed., Vol. 4, Issue 43). Wadsworth, Cengage Learning. https://doi.org/10.1017/CBO9781107415324.004

Babaii, E., \& Sheikhi, M. (2017). Traces of neoliberalism in English teaching materials: a critical discourse analysis. Critical Discourse Studies, 1-18. https://doi.org/10.1080/17405904.2017.1398671

Bhandari, H. (2019). English Textbook for Class Five: An Analysis. Journal of NELTA Gandaki, 1, $31-44$.

Bhatia, V. K. (1997). Introduction : Genre analysis and world Englishes. World Englishes, 16(3), 313-319.

Cho, Y., \& Park, Y. (2014). "Textbook as a contradictory meltingpot": an analysis of multicultural content in Korean textbooks. Asia Pacific Journal of Education, 1-21. 
Clariana, R. B., Wolfe, M. B., \& Kim, K. (2014). The influence of narrative and expository lesson text structures on knowledge structures: alternate measures of knowledge structure. Education Tech Research Dev, 1-16. https://doi.org/10.1007/s11423-014-9348-3

Courtis, J. K., \& Hassan, S. (2002). Reading Ease of Bilingual Annual Reports. . . Journal of Business Communication, 39(4), 394-413.

Dickens, R. H., \& Meisinger, E. B. (2017). Examining the effects of reading modality and passage genre on reading comprehension in middle school students. Reading Psychology, 38(3), 321347. https://doi.org/10.1080/02702711.2016.1263701

Edwards, H., Wesche, M., Krashen, S., Clement, R., \& Kruidenierr, B. (1985). Second-language acquisition through subject-matter learning: a study of sheltered subject matter classes at the University of Ottawa. The Canadian Modern Language Review, 41, 268-282.

Eggins, S. (1994). An introduction to systemic functional linguistics. Pinter.

Elley, W. (1991). Acquiring literacy in a second language: the effect of book based programs. Language Learning, 41(3), 375-411.

Elley, W., \& Mangubhai, F. (1983). The impact of reading on second language learning. Reading Research Quarterly, 19, 53-67.

Fauziati, E. (2014). Methods of Teaching English as a Foreign Language. Era PustakaUtama.

Feng, W. D. (2017). Infusing moral education into English language teaching: an ontogenetic analysis of social values in EFL textbooks in Hong Kong. Discourse: Studies in the Cultural Politics of Education, 1-16. https://doi.org/10.1080/01596306.2017.1356806

Fraenkel, J. R., Wallen, N. E., \& Hyun, H. H. (2012). How to design and evaluate research in education. McGraw-Hill Companies, Inc. https://doi.org/10.1017/CBO9781107415324.004

Gall, M. D., Gall, J. P., \& Borg, W. R. (2003). Educational research: An introduction (7th ed.). Allyn and Bacon.

Gebregeorgis, M. Y. (2016). Peace values in language textbooks: the case of English for Ethiopia Student Textbook. Journal of Peace Education, 1-15. https://doi.org/10.1080/17400201.2016.1228526

Groves, F. H. (2016). A longitudinal study of middle and secondary level science textbook vocabulary loads. School Science and Mathematics, 116(6), 106.

Halliday, M. A. K. (1985). An introduction to functional grammar. Edward Arnold.

Hauptman, P., Wesche, M., \& Ready, D. (1988). Second-language acquisition through subject matter learning: a follow-up study at the University of Ottawa. Language Learning, 38, 433471.

Joo, S. J., Chik, A., \& Djonov, E. (2019). The construal of English as a global language in Korean EFL textbooks for primary school children. Asian Englishes, 1-17. https://doi.org/10.1080/13488678.2019.1627636

Kalaycı, G. Ö., \& Diken, Ö. (2020). Relations between the Levels of Fluent Reading and Reading Comprehension and the Levels of Phonological Awareness of Individuals with Down Syndrome in Turkey. International Journal of Disability, Development and Education, 1-15. https://doi.org/10.1080/1034912X.2020.1727419

Ke, I. (2012). From EFL to English as an international and scientific language: analysing Taiwan's high-school English textbooks in the period 1952 - 2009. Language, Culture and Curriculum, 25(2), 173-187. https://doi.org/10.1080/07908318.2012.683530

Kherysuryawan. (2019). Silabus K13 bahasa Inggris kelas XI SMA revisi terbaru. https://www.kherysuryawan.id/2019/o7/silabus-k13-bahasa-inggris-kelas-xi-sma.html

Kirkpatrick, A. (2018). The development of English as a lingua franca in ASEAN. In J. Jenkins, W. Baker, \& M. Dewey (Eds.), The Routledge Handbook of English as a Lingua Franca (pp. 138150). Routlage.

Krashen, S. D. (1981). Second language acquisition and second language learning. Pergamon Press Inc.

Krashen, S. D. (1982). Principles and practice in second language acquisition. Pergamon Press Inc.

Krashen, S. D. (2004). The power of reading: insights from the research. Heinemann Publishers Ltd.

Lafayette, R., \& Buscaglia, M. (1985). Students learn language via a civilization course-a comparison of second language acquisition environments. Studies in Second Language Acquisition, 7, 323-342. 
Lauder, A. (2008). The status and function of English in Indonesia: A review of key factors. Makara, Social Humaniora, 12(1), 9-20.

Laufer, B., \& Nation, P. (1995). Vocabulary size and use: Lexical richness in L2 written production. Applied Linguistics, 16(3), 307-322.

Laufer, B., \& Nation, P. (1999). A vocabulary-size test of controlled productive ability. Language Testing, 16(33). https://doi.org/10.1177/026553229901600103

Lee, J. (2006). Subjunctive were and indicative was: a corpus analysis for English language teachers and textbook writers. Language Teaching Research, 10(1), 80-93.

Li, Y., Ma, X., Zhao, J., \& Hu, J. (2019). Graduate-level research writing instruction: Two Chinese EAP teachers' localized ESP genre based pedagogy. Journal of English for Academic Purposes, 1-43. https://doi.org/10.1016/j.jeap.2019.100813

Lin, L., Moore, D., Karen, M., \& Beach, L. (2000). Metacomprehension knowledge and comprehension of expository and narrative texts among younger and older adults. Educational Gerontology, 26(8), 737-749. https://doi.org/10.1080/036012700300001395

Marmolejo-ramos, F., Miller, J., \& Habel, C. (2014). The influence of question type, text availability, answer confidence and language background on student comprehension of anexpository text. Higher Education Research \& Development, o(o), 1-16. https://doi.org/10.1080/07294360.2013.863841

Mason, B., \& Krashen, S. (1997). Extensive reading in English as a foreign language. System, 25, 91-102.

Mauranen, A. (2018). Conceptualising ELF. In J. Jenkins, W. Baker, \& D. Martin (Eds.), The Routledge Handbook of English as a Lingua Franca (pp. 7-24). Routlage.

Morganna, R. (2017). Theoretical, pedagogical, practical views, and the shift of genre based instruction. English Franca, 1(1), 81-100. https://doi.org/http://dx.doi.org/10.29240/ef.v1i1

Morganna, R., Sumardi, \& Tarjana, S. S. (2020). Tertiary English students' attitudes towards intercultural language learning. Indonesian Journal of Applied Linguistics, 9(3), 657-665. https://doi.org/10.17509/ ijal.v9i3.23216

Nation, P. (2014). What do you need to know to learn a foreign language? School of Linguistics and Applied Language Studies Victoria University of Wellington.

Noviyenty, L., Morganna, R., \& Fakhruddin. (2020). The paradigms of teaching English across cultures: EFL teachers' perspectives. International Journal of Curriculum and Instruction, 12(1), 1-16.

Nunan, D. (2003). Practical English language teaching; Teacher's textbook. Mc Graw Hill Companies.

Pashmforoosh, R., \& Babaii, E. (2015). Whose Culture and How Far Culture Presentation in Current Business English Textbook Series. Journal of Teaching in International Business, 26(3), 216236. https://doi.org/10.1080/08975930.2015.1083514

Piaget, J. (1937). La construction du re'el chez l'enfant (In English, 1955: The Construction of Reality in the Child). Delachaux et Niestle'.

Purba, R. (2018). Improving the achievement on writing narrative text through discussion starter story technique. Advances in Language and Literary Studies, 9(1), 1-4.

Rahim, H. A., \& Daghigh, A. J. (2019). Locally developed versus global textbooks: an evaluation of cultural content in textbooks used in English language teaching in Malaysia. Asian Englishes, 1-15. https://doi.org/10.1080/13488678.2019.1669301

Rahmawati, M. R., Listiyani, A., \& Damayanti, S. (2014). The problems encountered by teachers in teaching procedure text. English Journal, 14(1), 45-55.

Rashidi, N., \& Kehtarfard, R. (2014). A Needs Analysis Approach to the Evaluation of Iranian Third Grade High School English Textbook. SAGE Open, 1-9. https://doi.org/10.1177/2158244014551709

Richards, J. C. (2001). Curriculum Development in Language Teaching. Cambridge University Press.

Roth, D. (2017). Morphemic analysis as imagined by developmental reading textbooks: A content analysis of a textbook corpus. Journal of College Reading and Learning, 47(1), 26-44. https://doi.org/10.1080/10790195.2016.1218807

Saadatnia, M., Tavakoli, M., \& Ketabi, S. (2016). EFL learners' levels of comprehension across text structures: A comparison of literal and inferential comprehension of descriptive and enumerative expository texts. Journal of Psycholinguistic Research, 1-15. https://doi.org/10.1007/s10936-016-9414-6 
Setyono, B., \& Widodo, H. P. (2019). The representation of multicultural values in the Indonesian Ministry of Education and Culture-Endorsed EFL textbook: a critical discourse analysis. Intercultural Education, 1-15. https://doi.org/10.1080/14675986.2019.1548102

Sherman, T. (2018). ELF and the EU/wider Europe. In J. Jenkins, W. Baker, \& M. Dewey (Eds.), The Routledge Handbook of English as a Lingua Franca (pp. 115-125). Routlage.

Shin, J., Eslami, Z. R., \& Chen, W. (2011). Presentation of local and international culture in current international English-language teaching textbooks. Language, Culture and Curriculum, 24(3), 253-268.

Sjøberg, S. (2010). Constructivism and learning. In P. Peterson, B. Eva, \& B. McGaw (Eds.), International Encyclopedia of Education (pp. 485-490). Elsevier. https://doi.org/10.1016/B978-0-08-044894-7.00467-X

$\mathrm{Su}, \mathrm{Y}$. (2014). The international status of English for intercultural understanding in Taiwan's high school EFL textbooks. Asia Pacific Journal of Education, 1-19. https://doi.org/10.1080/02188791.2014.959469

Subakir, M., Yasin, M., Hamid, B. A., Othman, Z., Bakar, K. A., Hashim, F., \& Mohti, A. (2012). A Visual Analysis of a Malaysian English School Textbook: Gender Matters. Procedia - Social and Behavioral Sciences, 69, 1871-1880. https://doi.org/10.1016/j.sbspro.2012.12.140

Syrbe, M., \& Rose, H. (2017). An evaluation of the global orientation of English textbooks in Germany. Innovation in Language Learning and Teaching, 1-12. https://doi.org/10.1080/17501229.2015.1120736

Thomas, N., Colin, C., \& Leybaert, J. (2019). Impact of interactive reading intervention on narratives skills on children with low socioeconomic background. European Early Childhood Education Research Journal, 1-23. https://doi.org/10.1080/1350293X.2019.1678924

Thuy, T., Nguyen, M., Marlina, R., Hong, T., \& Cao, P. (2020). How well do ELT textbooks prepare students to use English in global contexts? An evaluation of the Vietnamese English textbooks from an English as an international language (EIL) perspective. Asian Englishes, 1-17. https://doi.org/10.1080/13488678.2020.1717794

Uzun, K., \& Topkaya, E. Z. (2019). The Effects of Genre-Based Instruction and Genre- Focused Feedback on L2 Writing Performance. Reading \& Writing Quarterly, 1-24. https://doi.org/10.1080/10573569.2019.1661317

Vygotsky, L. (1978). Interaction between learning and development. In Readings on the Development of Children (pp. 34-40). https://doi.org/10.1016/Sooo6-3495(96)79572-3

Webb, S., \& Nation, P. (2017). How vocabulary is learned. Oxford University Press.

Worden, D. (2018). Balancing stability and flexibility in genre-based writing instruction: A case study of a novice L2 writing teacher. Journal of Second Language Writing, 1-14. https://doi.org/10.1016/j.jslw.2018.09.003

Wright, S., \& Zheng, L. (2018). Language as system and language as dialogic creativity: The difficulties of teaching English as a lingua franca in the classroom. In J. Jenkins, W. Baker, \& M. Dewey (Eds.), The Routledge Handbook of English as a Lingua Franca (pp. 506-517). Routledge.

Xiong, T., \& Qian, Y. (2012). Ideologies of English in a Chinese high school EFL textbook: a critical discourse analysis. Asia Pacific Journal of Education, 32(1), 75-92. https://doi.org/10.1080/02188791.2012.655239

Zawahreh, F. A. S. (2012). A content analysis of the vocabulary items in student's book of action pack seven as a textbook for teaching english as a foreign language in jordan. Continental $J$. Education Research, 5(1), 34-45. https://doi.org/10.5707/cjeducres.2012.5.1.34.45

Zhili, S. (2014). Ideology and Culture Behind an English Textbook for Chinese Universities. Asian Englishes, 2(2), 87-101. https://doi.org/10.1080/13488678.1999.10801033 